\title{
Kossinna Meets the Nordic Archaeologists
}

Evert Baudou

\begin{abstract}
The author discusses Montelius's, Aspelin's and Kossinna's ethnohistoric research and the development up to 1951. The starting point is a letter written by Kossinna in 1896 to Montelius in Stockholm. Kossinna's Siedlungsgeschichte and his tribal principle that cultural areas or cultural groups embodied a "Volk", are based on Montelius's paper from 1884/88 on the immigration of the ancestors of the Scandinavian peoples. Stringent European critics pointed out that Kossinna's method lacks any viable basis in theory. In spite of this the Scandinavian archaeologists continued the ethnohistoric tradition. In Finland there was marked criticism during the 1930s.
\end{abstract}

Evert Baudou, Department of Archaeology and Saami Studies, University of Umeå, SE-901 87 Umeå, Sweden.

Key words: Aspelin, ethnohistory, Kossinna, Montelius, Nordman, Siedlungsgeschichte, Tallgren, Wahle, Volk, Åberg.

\section{ETHNOHISTORY - AN ARCHAEOLOGICAL-HISTORICAL PROBLEM}

On March $13^{\text {th }}, 1896$, Dr Gustaf Kossinna, librarian at the Royal Library in Berlin, sent a letter about his archeological research to Oscar Montelius in Stockholm. This was accompanied by an offprint of a lecture he had given at a meeting of anthropologists in Cassel on August $9^{\text {th }}, 1895$, on the prehistoric diffusion of the Germanic peoples in Germany. In it Kossinna introduced a settlement archaeology, his Siedlungsgeschichte, which with its controversial methodology and arguable conclusions became a major source of contention among archaeologists in mainland Europe during the first half of the $20^{\text {th }}$ century. With or without the participation of the archaeologists, archaeological findings were also to be used as weapons in political debate during the period. Kossinna based his ideas on the typological methodology adopted by Montelius in his work on the chronology of the Nordic Bronze Age published in 1885, together with his reasoning on ethnic continuity in his essay Om varra förfäders invandring till Norden (On the immigration of our ancestors to the North) in 1884 (published in a German translation in 1888). Kossinna's settlement archaeology attained full development in his programmatic work Die Herkunft der Germanen in 1911. Large-scale application of the methodology resulted in the work Die deutsche Vorgeschichte eine hervorragend nationale Wissenschaft, addressed to a wide readership and published in eight editions between 1912 and 1941. 
Kossinna's work and his position in contemporary research in Europe can now be surveyed thanks to the comprehensive and penetrating biography published by Heinz Grünert in 2002. Another significant biographical contribution is Hildegard Schwerin von Krosigk's analysis (1982) of some of the documents bequeathed by Kossinna that were then in the keeping of the Institut für Ur- and Frühgeschichte at the University of Kiel (details of the fate of this collection can be found in Grünert 2002: 356-358). She also provides a catalogue of the letters contained in this collection with a summary of their main contents; 42 of the letters are published in their entirety.

When Kossinna came into prominence around 1900 he was one of many European humanists influenced by the nationalistic movements of the $19^{\text {th }}$ century. In order to understand how his research was received in Europe and the Nordic countries we have to view it through the eyes of his contemporaries, or in other words in its scholarly and at that time unquestionably national context, stage by stage from 1895 until his death in 1931. This becomes possible with the help of Grünert's comprehensive biography. The critical period that ensued was discussed at several symposiums. Numerous lectures on the relationship between prehistoric research and national socialism in Germany were edited by Heiko Steuer (2001), in Central and Eastern Europe by Achim Leube (2002).

During the period in which Kossinna was active, extensive ethnohistorical research was at the same time under way in the four Nordic countries as well. Nordic archaeologists based their research on Montelius's works or adopted similar approaches. No simple answers can be given to questions about the role played by Kossinna for Nordic archaeology as many aspects have to be taken into account. What standpoint was adopted by Montelius himself and other Nordic archaeologists to Kossinna's ethnic, settlement-archaeology based studies? Did Nordic archaeologists follow the example of Kossinna or did they take after Montelius and Aspelin to pursue an independent Nordic development? Can one discern any form of dialogue? What impact did continental criticism of Kossinna's methodology have in the Nordic countries? Kossinna's letter and his lecture provide the starting point for my discussion of ethnohistorical features in Nordic archaeology from 1900 until around 1950, which revolves around Kossinna. There is a wealth of material. I shall take up a few significant works that adumbrate the broad lines of ethnohistorical studies. I do not intend to deal with the links with the political debate (Baudou 2002a).

\section{ASPELIN, MONTELIUS AND KOSSINNA'S LETTER}

Attempts to use archaeological finds to help to determine prehistoric ethnic groups had already been taking place for a few decades in the Nordic countries when Kossinna penned his letter (Baudou 2004: 173-175, 182-186). The most extensive and in many ways the most successful attempt can be found in the five-volume work published by Johan Reinhold Aspelin, Antiquités du Nord Finno-Ougrien (1877-1884). Aspelin presumed that a large number of objects of the same 
characteristic type found in various parts of Finland and elsewhere outside Finland had belonged to one and the same "people". For instance he asserts (vol. IV, 1880:249) that a series of specific object types dating from the Late Stone Age through the Bronze Age to the Early Iron Age in western Finland betokened the same Scandinavian people as in Sweden, where these types were most frequent. He compares archaeological results with the linguistic findings. Prehistoric finds from the Late Iron Age, however, in the same area of western Finland consist of Finnish types, which Aspelin interprets as indicating population discontinuity (vol. IV, 1880:261). Identification of the archaeological material required the typological method developed by Hans Hildebrand and Montelius at the beginning of the 1870s and which Aspelin was familiar with (Baudou 2004: 190-191). The significance of the typological method was not only that the use of closed finds permitted the development of a relative chronology but also that it required identification of types through detailed and systematic study of the artefacts. The systematisation provided a survey of the extensive and partially unknown material in northern Russia and Siberia.

The next stage in this research in the Nordic countries can be found in Montelius' 1884 paper Om våra förfäders invandring till Norden (On the immigration of our forefathers to the North). The idea is fundamentally the same as Aspelin's but is formulated with greater clarity as a method that is based on identity and continuity. Determination of the identity of the population is based on the earliest historical information. Montelius wrote (1884a:28-29, 1888:155):

If the study of the prehistoric relics in the Nordic countries is to yield an answer to the question concerning the period in which our ancestors migrated here, we must start from the earliest period in which according to the historical testimony our forefathers lived here and then for every preceding period investigate whether prehistoric finds provide any grounds for assuming the immigration of a new people. Should there be no such grounds before the Stone Age, for example, then it is likely that little change has taken place for the bulk of the population since this period and that our Germanic forefathers therefore migrated here during the Stone Age.

Whether archaeological circumstances are able to provide information that a migration has taken place can be seen, for instance, from the Anglo-Saxon burial sites in England, from the Germanic burial sites during the Migration Period in France, Italy and several other countries, and also from the numerous relics left by the Scandinavian Vikings in the British Isles.

The German translation of 1888 was to provide one impulse for Kossinna, indeed one might even describe it as the spark that triggered Kossinna's future research (Eggers 1959:209).

In his letter in 1896 Kossinna describes how he has long been working on the history of the Germanic peoples and ethnography. He uses ethnography here to refer to ethnic identification based on ancient written sources. He cites as his 
principal teacher at the University of Berlin Karl Müllenhoff, Professor of German Philology specialising in Germanic Prehistory, a research specialisation established by Müllenhoff's predecessor Jacob Grimm. With regard to archaeology Kossinna writes (Schwerin von Krosigk 1982:168-169):

Among the Germans, only the unforgettable Tischler served me as a teacher and otherwise I have endeavoured mainly to follow in the footsteps of the Scandinavian masters, amongst whom you have always incontestably occupied the highest rank. Your masterly ingenuity revealed to me ten years ago ("Tidsbestämning") the methodological stringency that must prevail even in prehistoric studies and made me a lasting disciple of this science. Your works, of which 1 own several of those that have been published separately (such as "Tidsbestämning", "Kultur Schwedens", "Temps préhistorique en Suède"), have been my lodestar, as have your innumerable journal articles to perhaps an even greater extent.

The accompanying 14-page offprint of the lecture Die vorgeschichtliche Ausbreitung der Germanen in Deutschland (1896) is usually considered to mark the initiation of Kossinna's settlement-archaeology research. The five starting points for the methodology presented in the lecture are: as complete registration as possible of the material in the museums, typological specification of the material, ascription of dates to the types, mapping the distribution of the types with special reference to simultaneity and finally a discussion of the continuity of cultural remains and settlement from the earliest historically recorded circumstances back into prehistory and further through the various archaeological eras. The first three of these points can be found in Montelius's study from 1885. The methods adopted by Montelius and Kossinna on the fourth point diverged, with Kossinna placing great emphasis on detailed study of the geographic dispersal of contemporary types even though in practice he could not map so meticulously. Montelius described distributions that were not demarcated as clearly. The fifth point, the link with the historical periods and continuity go back to Müllenhoff's research and Montelius' paper. The German translation from 1888 is one of the papers referred to by Kossinna in his letter.

Kossinna (1896:8) begins his lecture in Cassel with the earliest historic sources and then moves backwards to the dispersal of Germanic culture during the Migration Period and the displacement of Slavic culture during the following centuries. For the Preroman Iron Age he traces references to Germanic and Celtic tribes in the classical texts and makes comparisons with finds and the distribution of funeral rituals, but also uses philological evidence. From the distribution of archaeological finds he considers himself able to determine the dispersal of populations and also displacements of settlements during the Preroman Iron Age. Features specific to the Nordic Bronze Age correspond to the distribution of the Germanic peoples during the Bronze Age. During the Late Bronze Age the Germanic settlements extend between the northern part of Weichsel and Oder, 
the inhabitants originating from southern Sweden and eastern Denmark. During the Late Stone Age an ethnic boundary is marked by the Kuyavian funeral sites, with their long trapezoidal mounds, east of the Oder. In the south and west, however, there are no such distinct population boundaries. As the boundaries of Germanic occupation seem to have contracted during the entire prehistoric period, their oldest home was to be found in Mecklenburg, Schleswig-Holstein, Jylland, the Danish islands and southern Sweden at the beginning of the third millennium B.C. (Kossinna 1896:14).

Kossinna's lecture at Cassel aroused no immediate reaction from his listeners. On the other hand there were some repercussions from the published version, offprints of which he sent to selected historians, philologists and archaeologists (Grünert 2002:67-70). Kossinna himself realised the significance of his lecture, it opened up a field of research that offered extensive scope.

\section{KOSSINNA AND THE NORDIC ARCHAEOLOGISTS UP TO 1911}

Grünert (2002:102) lists four fields for Kossinna's ethno-historical studies: the history of the Germanic tribes, the origin of the Germanic peoples and the primordial Indo-Germanic homeland, archaeological verification of the philological division into east and west Germanic and finally distinguishing between Germanic and Celtic. All of these areas are suggested in the Cassel lecture. All but the last were to play a role in Nordic research during the first half of the $20^{\text {th }}$ century. What is most important, however, is the stance generally adopted by Nordic archaeologists to Kossinna's methodology, i.e. to the principles of his settlement archaeology, which was criticised so trenchantly by archaeologists in Europe.

As Professor of German archaeology in Berlin from 1902, Kossinna lectured on the "tribal principle", an ethnic interpretation which according to him was the task of prehistoric research. The presence of contemporary archaeological types within an area signifies a culture. Cultural areas or cultural groups embodied a "Volk", cultural provinces were sub-divisions in which tribes or groups of tribes were ethnopolitical units (Grünert 2002:73). In his publication Die Herkunft der Germanen Kossinna (1911:3) formulated his oft-quoted cornerstone thesis: "Sharply defined archaeological provinces coincide with certain peoples or tribes throughout the ages." As there had since the dawn of history been thousands of examples to support this thesis, it must also apply to prehistoric periods, Kossinna claimed. It is possible that Kossinna had been influenced by the theory of the German-Austrian Kulturkreislehre, but nowhere does he refer to its representatives (Grünert 2002:72).

In these trenchant wordings we can see what distinguishes Montelius from Kossinna. Montelius is at pains to stress that archaeological circumstances can offer us information about a migration, not that it must provide a positive or negative response. In Johanna Mestorf's translation the German verb "k ö n n e n" is printed with spaced-out letters. In his work from 1911, Kossinna has reworded 
the first section of Montelius's text to read "Cultural continuity indicates the permanence of the population". Montelius's modest but nevertheless important reservation "probably" has disappeared. Montelius left scope for discussion, Kossinna excludes the possibility of argument. Nor does Montelius speak so categorically of sharply distinct areas.

Grünert (2002:215) lists several decisive points in the criticism expressed of Kossinna's methodology from its very inception. When Kossinna was dealing with archaeological and historical-philological sources he did not always observe "the most stringent degree of caution" that he himself required. The reasons for morphological and functional correspondences in both material and intellectual cultural relics may be the result of many different historical contingencies, and only in occasional cases is ethnicity one possibility among others. An absolute congruence between culture and ethnicity is not a rule, it has never been proved. The dogma cannot serve as a method of eliciting historical knowledge. Another crucial point is that Kossinna did not take adequate account of the way in which ethnogenetic formation is a permanent process that can take more or less time and may on occasions be punctuated.

The same criticism can in principle be expressed of the ethnic determination of prehistoric material by Montelius and Aspelin. When Montelius (1884b) reviewed Aspelin's major work he accepted and praised Aspelin's methodology and findings. However, in a scholarly review in 1885, Sophus Müller adopted a critical stance to the paper published by Montelius in the preceding year. It is courageous of Montelius, wrote Müller. "because if there is any error that one would wish to avoid with a "vestigia terrent', then this is it". "If this courage is to be rewarded, and if Dr. Montelius's theory is to endure, we cannot determine. But nevertheless the outcome is hardly certain." (Müller 1885:170). The archaeological material may not yet be able to furnish proof. Anthropological and linguistic aspects should be incorporated, and the archaeological studies extended well beyond the boundaries of the Nordic countries, in Müller's opinion.

Among the early critics of Kossinna Grünert (2002:117-122) lists several of the most eminent prehistoric scholars of the day: Moritz Hoernes in Vienna, Erazm Majewski in Warsaw, Sophus Müller in Copenhagen, Hans Seger in Breslau and Paul Reinecke in Mainz. Harsh criticism was expressed in particular of Kossinna's major paper from 1902, Die indogermanische Frage archäologisch beantwortet. Equating prehistoric pots with historical tribes seems to be a joke, a parody (Hoernes). The paper was the poisonous fruit of national chauvinism that promulgated goals that had nothing to do with scholarship (Majewski). It was necessary to proceed with caution, the time was not yet ripe to advance ethnic issues (Seger). All the criticism reverted to the lack of any theoretical basis for Kossinna's methodology.

A number of important Nordic works indicate that in these countries too archaeologists pursued their own approaches in the period around 1900 paying no heed to Kossinna. In a lecture in Helsinki in 1897, När kommo svenskarna till 
Finland (When did the Swedes come to Finland)?, Montelius offered an example of how his method from 1884 could be used. His starting point was the earliest historical records of Swedes in Finland and the earliest place-names. He then traced the material backwards from the Viking period through the Iron Age and Bronze Age to the Stone Age. The numerous Stone Age boat-axes from western Finland had features indicating that they were made in Finland in Montelius's opinion. This "local type" reveals to an even greater extent than their frequency that "a Swedish population was already at that remote period living in the country" (Montelius 1898:21). The conclusion was that there were already "Swedes" in Finland before 2000 B.C. They had migrated via Aland and the Gulf of Bothnia. In 1897, the Finnish archaeologist Hjalmar Appelgren was already able to demonstrate that the evidence presented during the lecture contained some weak points. Not enough research had yet been carried out in Finland. No ethnic conclusions can be drawn from funeral rites involving cremation or interment. Moreover, what can be considered evidence of cultural influence on autonomous domestic production and what the outcome of immigration? In a letter to Montelius dated July $22^{\text {nd }}, 1900$, on the other hand, Kossinna writes that he had much earlier come to the same conclusions about Swedish settlement on the coasts of Finland (Schwerin von Krosigk 1982:172).

Montelius's paper of 1898 provided the starting point for Knut Stjerna's once much discussed thesis Bidrag till Bornholms befolkningshistoria under järnaldern (Contribution to the history of the population of Bornholm during the Iron Age) of 1905. Stjerna had studied archaeology for Montelius and was awarded his doctorate in Uppsala under Oscar Almgren. He goes through the criteria for determining whether large or small scale migration has taken place with the help of changes in prehistoric types, burial sites and funeral rites. Only a few centuries before Christ one can observe "a remarkable dissimilarity in the nature and form of several prehistoric groups in various Nordic areas, dissimilarities that become more evident in the centuries after Christ" (Stjerna 1905:2). Stjerna is extremely familiar with Danish, Swedish and German research. In his review of the literature he refers several times to the North German archaeologists Götze, Beltz, Mestorf and Tischler. Migrations to and from the island during the Early Iron Age turn out to be highly dependent on conditions in the east Germanic areas south of the Baltic and on Gotland, Öland and in Kalmar Sound. Everything can be read from changes in burial sites and object types, sometimes with detailed interpretations that approach those of Kossinna (Stjerna 1905:251-256). However, Kossinna is cited only once, in a footnote reference to a paper from 1897 in which he links the name of Bornholm with the name of the Burgundian tribe (Stjerna 1905:132). Kossinna's archaeological research does not need to have been important for Stjerna. Montelius was his exemplar.

In the assessment he submitted to the Faculty of Arts at Uppsala, however, Almgren referred to Kossinna and Bernhard Salin (1904) as Stjerna's predecessors. Remarkably significant findings had been presented by Salin on the Germanic 
migrations and Kossinna on the early dispersal of the Germanic peoples. Stjerna was the first to try to draw detailed conclusions about the population history of a smaller area over a longer period of time. In his lectures on European archaeology Almgren was already mentioning Kossinna and his research in 1902 (Baudou 1997:128). Carl Johan Becker (1975:37-38; 1977:312), who also studied the prehistory of Bornholm writes that Stjerna's ideas never gained acceptance in Denmark but that the thesis is methodologically interesting and seems to have documentary support. The form of settlement changed during the $4^{\text {th }}$ century, but this was a general phenomenon in the surrounding geographic area as a whole. According to Becker, it is more difficult than ever to interpret these circumstances as evidence of migration to or from the island.

In Finland Alfred Hackman (1905) continued Aspelin's research into population developments in his thesis Die ältere Eisenzeit in Finnland which deals with the five centuries after Christ (Baudou 2004:223-225). In his preface he thanks Aspelin for his advice and encouragement. A thorough analysis of prehistoric finds and burial sites focuses on the problem of continuity. Using the largest possible number of sub-periods as he sifts the finds, he endeavours to follow cultural developments century after century. Although he takes philological results into account, his starting point is provided by the archaeological finds, which display both Scandinavian and Eastern Baltic features. This suggests a mixed population, a blend of cultures that increasingly acquired a Finnish stamp. For centuries there were peaceful invasions by a continuous stream of small groups of Finns from the Baltic coast to western Finland at the beginning of our era and they merged with the earlier population. Among researchers in the Baltic and northern Germany he makes special mention of Kemke, Tischler and Hausmann, Spitzin in St. Petersburg and Almgren and Salin in Sweden. Hackman (1905:332336) devotes detailed discussion to one section of Kossinna's Indo-Germanic work of 1902 that deals with the issue of the aboriginal population in the Baltic area and the emergence of the Latvian-Lithuanian group of peoples. He treats Kossinna with respect but is sceptical of his archaeological conclusions and queries the possibility of using archaeological research without recourse to philology to determine the emergence of a new populations like the Latvian-Lithuanian group. Although methodologically Hackman is close to Montelius and Kossinna, he uses much more extensive and carefully analysed archaeological material and his conversance with philology enables more penetrating scrutiny of both continuity and identity. On the whole, research in Finland continued to adhere to Hackman's results until the 1960s (Kivikoski 1964:128), abandoning them only when new archaeological finds altered attitudes to the sources.

\section{THE DIALOGUE BETWEEN NORDIC ARCHAEOLOGISTS AND KOSSINNA 1912-1931}

In 1912 Almgren published a discursive essay on Swedish-Finnish Stone Age issues. In it he attempts to present an "overview" in which he takes up five 
significant new publications (by Ailio, Brøgger, Kossinna, Stjerna, Ekholm). These were to provide some of the basis for Nordic Stone Age studies for many years to come. One of these publications is the first volume of Kossinna's Der Ursprung der Urfinnen und der Urindogermanen (1910). Almgren does not discuss problems of theory but whether or not the results of the different researchers concur in order to deduce the most probable opinion. He takes Montelius's 1884 essay as his given starting point. There is no mention of the extensive criticism of Kossinna that had already been levelled by European researchers. The "BoatAxe culture" of south-western Finland betokens "with the utmost probability" a Scandinavian, Germanic population. Appelgren's criticism is not referred to. A cultural boundary is also a population boundary. Almgren (1912:75) criticises Kossinna's opinion that the Finno-Ugrians correspond to "the brachycephalic elements in the Nordic population". This is too hasty an assumption that involves great contradictions and difficulties. The anthropological material from the area is still extremely meagre. Almgren himself, however, poses a number of rash questions about race which indicates the enormous interest, if not fascination, race issues gave rise to in the period.

There can be no doubt that Almgren was deeply influenced by Kossinna's methodology. In a letter to Kossinna dated July $12^{\text {th }}, 1905$, he writes of the latter's long paper on the east Germanic problem (Kossinna 1905): Almgren is struck by the way in which the archaeological results all coincide to provide a solid foundation for ethnic conclusions (Schwerin von Krosigk 1982:178). He was waiting for the establishment of something epoch-making in the study of the early Germanic peoples (August 1905; Schwerin von Krosigk 1982:114). The material presented by Kossinna, however, was never to provide a firm enough foundation, on the contrary it was criticised for its inadequacies.

Of the Nordic researchers Sophus Müller repudiated Kossinna most vehemently, although in reality not his methodology but his results. In the criticism of Montelius's 1884 paper cited above, Müller advocated the exclusion of ethnic issues from prehistoric research. In Vor Oldtid Müller (1897) also provides no answers to questions concerning the ethnicity of the population in all three prehistoric eras. But excavations in the 1890 s of the many small mounds in central Jylland with their distinctive graves and Stone Age objects focused attention on the issue. These finds were at complete variance with the material familiar from Megalithic graves. As early as 1898, Müller published a long paper on this continuity gap, interpreting it to indicate the immigration of a new population. The excavations and their interpretation now became part of the intensive discussion about prehistoric ethnicity that Kossinna's publications were then beginning to provoke. In a letter to Kossinna of February $9^{\text {th }}, 1903$, Müller affirms his great interest in his publication on the Indo-Germanic peoples and in his methodology (Schwerin von Krosigk 1982:176). He has a lot to say but not by letter and hopes to meet Kossinna for a thorough discussion. This meeting never took place. Müller's application of Kossinna's methodology yielded results that completely 
contradicted Kossinna's interpretations. Their scholarly differences were compounded by the fiercely nationalistic standpoints adopted by the two in the impending political crisis. The major conference on Baltic archaeology held in Stockholm in 1912 attracted representatives from all of the Baltic states except Denmark.

In 1914 Müller published an ethnic interpretation of the continuity gap in Stone Age Denmark, placing it in the context of the Aryan problem or, using Kossinna's terminology, the Urheimat, the original Indo-Germanic homeland. Both southern and northern Europe received groups of immigrants from the original Aryan homeland in Central Europe. In Jylland the immigrant "Single Grave culture" was Aryan. The Megalith Grave culture on the coast would then belong to an earlier, non-Aryan group whose origins were to be found in the western coasts of Europe. The ancestry of the Danes could be traced back to the fusion of peoples that took place during the third and second centuries before Christ.

In the following year Müller continued with a comprehensive paper on the Bronze Age in Sønderjylland, in which he uses Kossinna's method for determining ethnicity. Sønderjylland was part of the ancient Danish area where complete cultural community prevailed during the Early Bronze Age. There was no reason to assume any differences in the population that succeeded the fusion of peoples in the late Stone Age. Nothing suggested that a new people had migrated into the area at the beginning of the Bronze Age. Müller was highly critical of Kossinna's failure to perceive the distinct difference between Germanic and Nordic artistic expression. Germanic bronze objects from Bronze Ages sites outside ancient Denmark revealed a predilection for exaggeratedly large, massive, conspicuous, heavy and crude objects. This is almost the opposite of Nordic Bronze Age objects. "Here we are confronted with a contingency that is rooted in the spirit of the people." (Müller 1915:277). Southern Scandinavia and the north-German coast could not be united to form an ur-Indo-Germanic area. At the first Nordic Archaeological Conference, held in Kristiania (Oslo) in 1916, Müller continued his attack on Kossinna. It was not merely a matter of contending with bad hypotheses but of shifting away from a "hypothetical archaeology" to one based on observations (reported by Helge Gjessing 1918:188). Once the advocate of caution and "vestigia terrent", Sophus Müller had now accepted Kossinna's ethnohistorical methodology and was using it in a scholarly and political contest with him.

Montelius realised that he was obliged to express an opinion in this conflict about the origin of the Nordic peoples. In a paper from 1917 he has abandoned the wording "the ancestors of the Scandinavian peoples" and speaks instead of the "the home of the Germanic peoples". He returns to his paper of 1884 and depicts the continuity of the population from the beginning of the Stone Age. Physical anthropology also indicates the same enduring lineage. It turns out that the home of the Germanic peoples in the very earliest period was "mainly in the three Scandinavian countries together with a small area in northern Germany". 
(Montelius 1917:405). During the Bronze Age and the Early Iron Age this area was extended. New excavations and careful analyses now show that the Germanic tribes in the Migration Period in Europe came not only from northern Germany but also from Scandinavia. Montelius refers, among other examples, to Bornholm and the Burgundians. One result of the Migration Period, for instance, was the population of southern Germany by Germanic peoples and the displacement of the Celts. "If we take blood into account, and not temperament, the majority of southern Germans are much more purely Germanic than the majority of northern Germans" (Montelius 1917:412). In this statement, which is remarkable in every way Montelius uses the word "blood", which had not used in 1884. At the beginning of the $20^{\text {th }}$ century research on racial biology evolved in Sweden and it was to develop into racism and influence a number of archaeologists (Baudou 1997:162-164). Montelius's pronouncements on pure Germanic blood and the great value he attributed to it could be seen as one outcome of the influence of this racial biology. The even more extreme racial biological values expressed by Kossinna may also have played their part.

In a paper on the homeland of the Aryan people, published a year after his death, Montelius took the final step in his endeavours to trace the ultimate origins of the Scandinavian peoples. When the inland ice receded, people belonging to the Cro-Magnon race migrated into Scandinavia from central Europe. Although these people were not Germanic they were the ancestors of the Germanic peoples. They lived separately from the other peoples in Europe and had become "gradually, through a natural differentiation, Germanic, in the same way as those living in western Europe became Celts and those in the east Slavs." (Montelius 1922:408). This and the dispersal of the Aryan languages was said to provide strong grounds for believing that originally the Aryans had inhabited the ice-free areas of central Europe from the Atlantic to Austro-Hungary. This paper fails to adhere to the methodology that Montelius had himself proposed in 1884, the material does not provide support for its far-reaching conclusions, identity and extended continuity is taken for granted without discussion. It is an incomplete conceptual draft that fails to do justice to Montelius's achievements in the decades prior to 1900 .

A total of 39 of the letter written by Kossinna to Montelius in the long period between 1896-1918 have been preserved ( (Schwerin von Krosigk 1982:139140). Montelius's letters on the other hand have disappeared, probably plundered at the end of the war (Grünert 2002:357). Kossinna's letters deal with archaeological issues, but above all contain requests for Montelius to send his publications, which he also did unstintingly. The tone is very friendly, after 1912-13 more candid.

Before Montelius' death in 1921, Kossinna had already established close contact with Nils Aberg (1888-1957), who assisted him with archaeological texts in Swedish and information from museums. Aberg had studied at Uppsala under Almgren, where he had also taken his doctorate. The Aberg file at the Antiquarian 
Archive in Stockholm contains 64 letters and cards sent by Kossinna between 1916 and 1931, and a greeting from 1912. Schwerin von Krosigk was not aware of this collection in 1982. The Kossinna archive in the archives of the Humboldt University contains a few of Åberg's responses. The tone of these letters is one of professional intimacy. After Kossinna's stay in Sweden in 1930, when he visited the Historical Museum and met Åberg and his parents, Kossinna addresses him as "Lieber Freund" and writes on personal matters.

A berg soon devoted his research to links between Scandinavia and the Continent. In his thesis in 1912 on contacts between the Nordic countries and Western Europe during the Late Stone Age, he analysed material from about 40 museums and private collections in Scandinavia and Western Europe. He then rapidly increased his knowledge of the material by making many trips to the Continent. The breadth of his perspective and his efficiency made Åberg a very suitable contact. Moreover Åberg's approach was similar to Kossinna's and he used his methodology. The frequency of their correspondence at times and the many questions that demanded immediate response demonstrates its significance for Kossinna. Åberg also benefited from his excellent relationship with Kossinna during his visits to Germany.

Åberg's early collections of material received a positive reception from a wide group of archaeologists, as can be seen from a long article by Albert Kiekebusch under the entry "Typenkarte (Deutschland)" in Ebert's influential Reallexikon der Vorgeschichte (1929:503-508). At the end of the $19^{\text {th }}$ century publication had begun of maps showing the dispersal of archaeological types. At a meeting in 1902, the German Anthropological Society had decided to start systematic mapping. This would provide an overview of the distribution of the types, the probable sources of the types, the boundaries of certain archaeological provinces and perhaps of peoples. The results were published in Zeitschrift für Ethnologie 1904-1914. Kiekebusch provides a surprisingly detailed account of Åberg's technical success in producing what were for the time excellent dispersal maps in three earlier publications using various symbols in red and black. Kiekebusch says nothing about Åberg's conclusions. Åberg's interpretation of the maps largely adopts Kossinna's ideas about migrations from north to south but is based on a detailed dispersal of specific types. Both Montelius and Kossinna emphasised a holistic approach. Åberg's work from 1918 on the Nordic cultural sphere in central Europe in the Late Stone Age has greater merit. In it he analyses material from about 80 museums in central Europe and the area south of the Baltic. Only three museums are included in both works from 1912 and 1918. A berg recorded different types of stone axes and ceramics and developed an overall view that accorded more readily with the demands of the time than his first work and which was received with interest. He follows Kossinna, although at times he rejects aspects of his hypotheses.

Kiekebusch (1929:508) concludes with a new publication by Karl Herrmann Jacob-Friesen which is still of significance today. This is a systematic, critical 
analysis of the fundamental issues in prehistoric research on race, peoples and cultures. One section deals with interpretation and includes problems of ethnicity. The chapter on methodology contains a section called the chorological method, which involves not only a cartographical account of dispersal but also evaluation of the cartographic image (Jacob-Friesen 1928:174). Types may have differing "chorological sensitivity", i.e. they may be dispersed widely or be found within a small, delimited area. The widespread forms are referred to as "inter-regional", the others as "regional". Jacob-Friesen's first presentation of his proposal in 1921 and his subsequent critical development of his arguments on the significance of the diffusion of inter-regional types, by trade, the dissemination of ideas and migration, involved a major step forward for archaeological research. Maps of types were superimposed to determine areas with contemporary stylistic features and these in their turn to indicate cultural spheres. Chronological problems arise and then, "but not until then - can we answer many of the cultural and genetic questions in prehistoric research, whose solutions today we are attempting to reach through mere speculation." (Jacob-Friesen 1928:187). Jacob-Friesen continually reiterates swingeing criticism of Kossinna's hypotheses and rejects them, mainly because they are proposed with no material to substantiate them. On the other hand he has a very positive opinion of Åberg's work, which he considers to be a highly interesting attempt to establish a prehistoric ethnic methodology. Jacob-Friesen concludes his section on the Germanic peoples by referring back to Montelius as the first (1884) to lay claim to the Nordic cultural sphere for the "ancestors of the Germanic peoples". However, he did not speak of "Germanic peoples" but merely of the "ancestors of the Germanic peoples". As cultural historians, Jacob-Friesen writes, where the Stone Age and Bronze Age are concerned we should be even more cautious and merely speak of stylistic and cultural spheres and choose neutral geographical denominations instead of ethnic ones.

Kossinna died in 1931. Impending political changes were to enhance the significance of his work irrespective of scholarly criticism. Nor does the criticism of Jacob-Friesen and others seem to have had much impact in Sweden. In the Scandinavian countries, archaeological research from the latter part of the 1920 s and onwards mainly turned its attention to new problem areas (Baudou 2004: 264-273). On the other hand ethnohistoric research continued in Finland.

\section{ETHNOHISTORICAL EVALUATIONS IN THE NORDIC COUNTRIES 1931- 1951}

After Hackman a number of significant works were published in Finland by Aarne Mikael Tallgren, Julius Ailio and Aarne Äyräpää (Baudou 2004: 264-273). Two methodologically important papers by Tallgren and Carl Axel Nordman took issue with Kossinna's Siedlungsarchäologie. Tallgren continued Aspelin's research in Russia and Siberia and attained new results. In 1923 he was appointed to the chair of Finnish and Nordic Archaeology at Helsinki University. For the Inter- 
national Archaeological Congress in Oslo in 1936 he published an article "Sur la méthode de l'archéologie préhistorique" in his internationally recognised series Eurasia Septentrionalis Antiqua. Tallgren opposes the stereotypical way in which prehistoric archaeology deals with historical and cultural manifestations. In every culture rudimentary elements survive to exist side by side with the new, in no country has a totally uniform development been found. Every cultural sphere provides scope for many different ways of life. He takes up cudgels against the tendency to seek primarily for a "people", a uniform population, behind a material culture. Cultural movements have become migrations of "peoples" and not changes within social groups or trade. Tallgren uses a late example from Siberia to demonstrate that it is possible for the material culture of one "people" to divide into two. On the other hand the similarity between the material cultures of two different groups may make it difficult to distinguish two different "peoples". "Peoples" are the outcome of history, not of nature and not at all of race. Culture is a social product and must be studied as such. Leo Klejn (1974:35) in a paper published in what was then the DDR expressed the opinion that the influence of Soviet researchers is clearly discernible in a work by Childe from 1935 as it is in Tallgren's paper in 1936 (which is not listed in Klejn's list of references). Tallgren (1936:23-24) distanced himself firmly from both Communism and Nazism. He took issue with the dogmatism and schools of both Russian and German "Archaeology", which were not based on science but sought corroboration in the works of the political authorities, even including quotations from Marx, Lenin, Engels, Stalin and Hitler. Tallgren's and Eurasia's major international reputation meant that attention was paid to his political strictures and not perhaps to his scholarly criticism to the same extent. One of those who did perceive the major theoretical value of the article was Ernst Wahle (1951:90). Tallgren's article was first published in Finnish in 1935 and subsequently in English, Polish and Spanish versions (Kivikoski 1954:111).

Between 1912 and 1919 Nordman studied and worked at the National Museum in Copenhagen while Sophus Müller was still its director. He began a lecture in Swedish in 1928, Kultur och folk $i$ Finlands forntid (Culture and the people of Finland in prehistory), with the crucial questions:

/To/ what extent is a distinctive culture, as it materialises in prehistoric finds, an expression of the individuality of a people? Indeed, is one of the requirements for a homogenous culture a homogenous population, or can culture extend beyond ethnic boundaries? ... What then is the relationship of culture to the people that sustain it? (Nordman 1928:132).

If the material is meagre and one-sided then not even after scrupulous analysis can it be used to solve the problems. One example from recent history demonstrates the impossibility of using material culture to distinguish between Swedes and Finns in western Finland. 
We must therefore abandon the hope of being able to solve all the archaeological equations using the simple formula: cultural areas are the same as the areas inhabited by one people. ... Emancipated from the dogma, it is possible to work without prejudice, appraise each individual case to the best of one's abilities ... (Nordman 1928:133).

The criticism is the same as that earlier expressed on Kossinna in Germany. The are also striking similarities with the criticism expressed by Jacob-Friesen in the same year. In an English version of the lecture Nordman starts by declaring that Finland lies on the boundary between different cultures, which enables investigation of the degree to which national characteristics find expression in archaeological finds (Nordman 1933:111). The English lecture follows the same lines as the 1928 lecture and is to a large extent a translation of the Swedish.

Nordman was invited to the University of Berlin by Kossinna's successor, Hans Reinerth, in 1937 to give a lecture in a series entitled "Germany and the Nordic Countries". In the same year this lecture was published in Mannus, once Kossinna's own journal. The text is an edited version of the 1928 lecture. A direct translation of the attack on Kossinna's settlement archaeology can still be found but this has been tempered by the omission of the words "dogma" and "without prejudice". The lecture is objective and purely archaeological with none of Kossinna's speculative interjections on ur-Indo-Germanic homelands, IndoGermanic peoples, pre-Finns and ur-Finns. Despite some degree of adaptation to the Berlin venue, the German text could be considered provocative. In Reinerth's letter thanking Nordman he says that the lecture had made a deep impression, which was probably accurate.

Ernst Wahle, Professor at Heidelberg, had taken note of Nordman's lecture. A few years later he published his remarkable work on ethnic problems in prehistoric studies with extensive discussion and criticism of Kossinna's settlement history methodology. He had already established himself as an independent critic but 1941 was a surprising date to choose for the publication of this new work. The edition sold out within a year. One of the works Wahle cited in support of his criticism is half a page of Nordman's article in Mannus giving the example of the impossibility of using material culture to distinguish between Swedish and Finnish in western Finland. (Wahle $2^{\text {nd }}$ ed. 1952:109; refers to Nordman 1937:480 and 1928:132).

To the best of my knowledge, the criticism of the shortcomings of Kossinna's ethnohistorical methodology expressed by Nordman and Tallgren was never to play any role in the Scandinavian countries. In 1949 A berg published a retrospective review of the Nordic Stone Age studies in which relationships with Kossinna's results were significant. But Åberg makes no mention of German criticism of Kossinna's methodology at the beginning of the century, nor of the criticism of Jacob-Friesen, Wahle, Nordman and Tallgren. On the other hand he does discuss Sophus Müller's criticism of Kossinna's results, fully aware that Müller 
had applied his methodology. In the context of research in the $1930 \mathrm{~s}$, Åberg takes sharp exception to the lively description of the struggle between the invading "Single Grave People" and the vanquished "Megalith Grave People" during the Late Stone Age contained in Johannes Brøndsted's Danmarks Oldtid 1938. Sune Lindqvist (1939), on the contrary, had only praise for the dramatic narrative.

The final thesis in the Mannus-Bibliothek, launched by Kossinna in 1910, was to be Eric Oxenstierna's Die Urheimat der Goten which is based totally on Kossinna's methodology (Baudou 2002b:184-185). Oxenstierna had studied under Reinerth in Berlin from 1940-1943 and his thesis was printed in Leipzig. The bulk of the edition went up in flames during the final weeks of the war in 1945, but some of the volumes had been transferred to Sweden. In 1948 Oxenstierna defended his thesis at Uppsala for Sune Lindqvist, who assessed it as poor but passed it. Rolf Hachmann published a review in Germania in 1951 which was a coming to terms with Kossinna. Oxenstierna had not perceived Kossinna's greatest error, which was to project Romantic ideas of a people's shared identity on to the archaeological finds. No such shared identity has been attained at any time or in any place. In the thesis the concept of people undergoes no change in any period and culture has become the aggregate of individual cultural elements that are continually developing. Oxenstierna has no concept of complex functional contexts. He does not seek tangible empiricism but strays into fruitless speculation.

In 1951 Gutorm Gjessing published a paper, "Arkeologi og etnografi", in Viking that presages the changed approach that was later to be adopted to archaeological research. Gjessing no longer speaks of "cultural history" but "cultural studies". Tired of the multitude of terms like "Komsa culture", "Magdalenien culture" etc. Gjessing writes (1951:220-221):

Culture does not at all consist of objects or patterns of behaviour, but of the content of the ideas that underpin visible manifestations. Culture consists of the feelings and objectives, the value judgements and the knowledge that determine lifestyles. For that reason culture cannot on the whole be discerned; it is a purely mental phenomenon.

Is the aim of archaeology to be content to provide no more than a merely descriptive analysis of prehistoric life or should it endeavour to fathom the cultural forces that have shaped the environment through unending cultural change? Gjessing considers that archaeological research has placed much more emphasis on the external causes of what has happened than on cultural and social impact.

\section{CONCLUSION}

At the beginning of the $20^{\text {th }}$ century Nordic archaeologists were adopting Montelius's ethnohistorical methods which were based on identification of object types and their continuity in time and place. In Finland Aspelin was the pioneer. Kossinna's settlement archaeology was similarly based on Montelius and was readily accepted by scholars such as Almgren, Stjerna and Åberg. Montelius 
himself was more cautious and had clearly perceived the minor but decisive differences between his methods and Kossinna's. To begin with Sophus Müller rejected the methodology but then went on to apply it uncritically. In Finland Appelgren was already expressing critical opinions in 1897. Hackman added more. There was no dialogue between Nordic archaeologists and Kossinna worth speaking of. Apart from Montelius, there were no other archaeologists that Kossinna listened to. On the other hand a respectful and good relationship was maintained on both sides. Here Sophus Müller was the exception.

Underlying Kossinna's methodology is the implicit theory that identity and changes in archaeological finds always correspond to identity and changes in groups of people, an idea that is contradicted by empiricism. The conceptual error is of the same kind as when an object type is presented in a typological description as if it were a living being undergoing change. Montelius's original wording contains no "always" but that it possibly "can". Right from the beginning of the century, stringent European critics have repeatedly pointed out that Kossinna's Siedlungsgeschichte lacks any viable basis in theory. It is remarkable and difficult to explain why the Scandinavian archaeologists did not discuss all the criticism expressed. On the contrary, Scandinavian archaeologists of the generation succeeding Montelius and Müller, such as J. Brøndsted, S. Lindqvist, N. Åberg, A.W. Brøgger and H. Shetelig, continued the ethnohistoric tradition but often in opposition to Kossinna's results. In Finland, on the other hand, criticism of Kossinna's method became clamorous during the 1930s with Nordman and Tallgren. At the same time G. Hatt gave settlement archaeology new content with his field excavations of houses and farms in Jylland. In Norway A.W. Brøgger launched settlement or rather landscape archaeology of a geographical-ethnological nature. When Hachmann in 1951 put paid to Kossinna's Siedlungsarchäologie in his review of Oxenstierna's thesis on the homeland of the Gotones, Gutorm Gjessing was already advocating social-anthropological archaeology.

Translated by David Jones. 


\section{REFERENCES}

\section{HANDWRITINGS}

Antikvarisk topografiska arkivet (The Antiquarian Archive), Stockholm

Oscar Montelius arkiv, Brevsamlingen, Vol.72, G. Kossinna.

Nils Åbergs arkiv, Brevsamlingen, G. Kossinna.

Helsingfors Universitetsbibliotek, Helsingfors

SLSA, C.A. Nordmans arkiv, Signum 652.6, H. Reinerth 16/5 1937.

Uppsala universitets arkiv, Universitetsbiblioteket, Uppsala

Fakulteternas arkiv: AIb:12, O. Almgren 27/09 1905 (K. Stjerna).

Alb:55, S. Lindqvist 24/2 1948 (E. Oxenstierna).

\section{PUBLISHED TEXTS}

Almgren, O. 1912. Några svensk-finska stenåldersproblem. Ett orienteringsförsök. Antikvarisk tidskrift för Sverige XX:1.

Appelgren, H. 1897. Svenskarnes inflyttning i Finland. Finskt Museum 1897. Pp.17-29.

Aspelin, J.R. 1877-1884. Antiquités du Nord Finno-Ougrien I-V. Helsinki.

Baudou, E. 1997. Gustaf Hallström - arkeolog $i$ världskrigens epok. Vitterhetsakdemiens skriftserie

Svenska Lärde. Natur och Kultur. Stockholm.

- 2002a. Arkeologi och politik i Sverige 1921-1945. Kungl. Vitterhets Historie och Antikvitets Akademiens

Årsbok 2002. Pp. 57-68. Stockholm.

- 2002b. Åberg, Montelius och Kossinna. Fornvännen 97. Pp. 177-190.

-2004. Den nordiska arkeologin - historia och tolkningar. Kungl. Vitterhets Historie och Antikvitets

Akademien. Stockholm.

Becker, C.J. 1975. Hovedlinier i Bornholms oldtidshistorie. Bornholmske samlinger 1975. Pp. 1-41.

- 1977. Bornholm. Reallexikon der Germanischen Altertumskunde. Band 3. Pp. 297-313.

Brøgger, A.W. 1925. Det norske folk $i$ oldtiden. Instituttet for sammenlignende kulturforskning. Oslo.

Brøndsted, J. 1938. Danmarks Oldtid I. Stenalderen. København.

Eggers, H.J. 1959. Einführung in die Vorgeschichte. E. Pipers \& Co. Verlag. München.

Gjessing, G. 1951. Arkeologi og etnografi. Viking XV. Pp. 215-235.

Gjessing, H. 1918. Det første nordiske arkeologmøte. Kristiania 4-8 juli 1916. Oldtiden VII. Pp. 187-217.

Grünert, H. 2002. Gustaf Kossinna (1858-1931). Vom Germanisten zum Prähistoriker. Ein Wissenschaftler im Kaiserreich und in der Weimarer Republik. Vorgeschichtliche Forschungen Band 22. Verlag Marie Leidorf GmbH. Rahden/Westf.

Hachmann, R. 1951. Review of Oxenstierna, E. 1945/48. Die Urheimat der Goten. Germania 29. Pp. 98101.

Hackman, A. 1905. Die ältere Eisenzeit in Finnland. Die Funde aus dem fünf ersten Jahrhunderten n. Chr. Helsingfors.

Jacob-Friesen, K.H. 1928. Grundfragen der Urgeschichtsforschung. Stand und Kritik der Forschung über Rassen, Völker und Kulturen in urgeschichtlicher Zeit. Hannover.

Kiekebusch, A. 1929. Typenkarte (Deutschland). In: Ebert, M. (Ed). Reallexikon der Vorgeschichte.13. Band. Pp. 503-508.

Kivikoski, E. 1954. A.M. Tallgren. Eurasia Septentrionalis Antiqua. Supplementary volume. Pp. 77-121.

- 1964. Finlands förhistoria. (1961. Suomen esihistoria). Helsingfors.

Klejn, L. 1974. Kossinna im Abstand von vierzig Jahren. Jahresschr. f. Mitteldt. Vorgesch. 58. Pp. 7-55.

Kossinna, G. 1896. Die vorgeschichtliche Ausbreitung der Germanen in Deutschland. In: Zeitschr. d. Vereins $f$. Volkskunde. 6. Pp. 1-14.

- 1902. Die indogermanische Frage archäologisch beantwortet. Zeitschr. f. Ethn. 34. Pp. 161-222.

- 1905. Verzierte Eisenlanzenspitzen als Kennzeichen der Ostgermanen. Zeitschr. f. Ethn. 37. Pp. 369-407.

- 1909/10. Der Ursprung der Urfinnen und der Urindogermanen und ihre Ausbreitung nach dem Osten. Mannus 1. Pp. 17-52, 225-245. Mannus 2. Pp. 59-108. 
- 1911. Die Herkunft der Germanen. Zur Methode der Siedlungsarchäologie. Mannus-Bibl. 6. Würzburg. - 1912. Die deutsche Vorgeschichte eine hervorragend nationale Wissenschaft. Mannus-Bibl. 9. Würzburg. Leube, A./Hegewisch, M.(Eds). 2002. Prähistorie und Nationalsozialismus. Die mittel-und osteuropäische Ur- und Frühgeschichtsforschung in den Jahren 1933-1945. Studien zur Wissenschafts- und Universitätsgeschichte. Band 2. Heidelberg.

Lindqvist, S. 1939. Aktuella stenåldersproblem. Ymer 59. Pp. 113-130.

Montelius, O. 1884a. Om våra förfäders invandring till Norden. Nordisk Tidskrift 1884. Pp. 21-36. In German by Mestorf, J. 1888. Ueber die Einwanderung unserer Vorfahren in den Norden. Arch.f.Anthr. Band XVII. Pp. 15I-160.

- 1884b. Review of Aspelin, J.R. 1877-1884. Antiquités du Nord Finno-Ougrien I-V. Nordisk Tidskrift 1884. Pp. 83-84.

- 1885. Om tidsbestämning inom bronsåldern med särskildt afseende på Skandinavien. Kungl. Vitterhets Historie och Antikvitets Akademiens Handlingar 30. Stockholm. In: English 1985. Dating in the Bronze Age with special reference to Scandinavia. KVHAA.

- 1898. När kommo svenskarna till Finland? Finsk Tidskrift 44. Pp. 81-105.

- 1917. Germanernas hem. Nordisk Tidskrift 1917. Pp. 401-416.

- 1922. De ariska folkens hem. Nordisk Tidskrift 1921. Pp. 401-418.

Müller, S. 1885. Nordens forhistoriske archæologi i 1883-1884. Nordisk Tidskrift 1885. Pp. 163-179.

- 1897. Vor Oldtid. Danmarks forhistoriske Archaoologi. Kjøbenhavn.

- 1914. Sønderjyllands Stenalder. Aarbøger for nordisk Oldkyndighed og Historie 1913. Pp. 169-322.

- 1915. Sønderjyllands Bronzealder. Aarbøger for nordisk Oldkyndighed og Historie 1914. Pp. 195-322.

Nordman, C.A. 1928. Kultur och folk i Finlands forntid. In: Svenska Litteratursällskapets Förhandlingar N.F. 4. Pp. 131-148. Helsingfors.

- 1933. The Cultures and Peoples of Prehistoric Finland. Journal of The Royal Anthropological Institute of Great Britain and Ireland. Vol. LXIII. Pp. 111-122.

- 1937. Germanen und Finnen in der Vorgeschichte Finnlands. Mannus 29. Pp. 477-501.

Oxenstierna, E. 1945/48. Die Urheimat der Goten. Leipzig/Stockholm. (Mannus-Bibl. 73.)

Salin, B. 1904. Die altgermanische Thierornamentik. Typologische Studie über germanische Metallgegenstände aus dem 4. bis 9. Jahrhundert nebst einer Studie über irische Ornamentik. Stockholm. (Reprinted 1935 Stockholm \& 1981 Leipzig.)

Schwerin von Krosigk, H. 1982. Gustaf Kossinna. Der Nachlass. Versuch einer Analyse. Offa. Erg.-R. 6. Neumünster.

Steuer, H. (Ed). 2001. Eine hervorragend nationale Wissenschaft-Deutsche Prähistoriker zwischen 1900 und 1995. Ergänzungsband zum Reallexikon der Germanischen Altertumskunde. Band 29. Walter de Gruyter. Berlin - New York.

Stjerna, K. 1905. Före Hällkisttiden. Antikvarisk Tidskrift XIX:2.

Tallgren, A.M. 1936. Sur la méthode de l'archéologie préhistorique. Eurasia Septentrionalis Antiqua X. Pp. 16-24.

Wahle, E. 1941. Zur ethnischen Deutung frühgeschichtlicher Kulturprovinzen. Grenzen der frühgeschichtlichen Erkenntnis I. Sitzungsberichte der Heidelberger Akademic der Wissenschaften. Philosophischhistorische Klasse.1940/41, 2. (2. unveränd. Aufl. 1952). Heidelberg.

- 1951. Geschichte der prähistorischen Forschung. (Schluss). Anthropos 46. Pp. 49-112.

Åberg, N. 1912. Studier öfver den yngre stenåldern i Norden och Västeuropa. Norrköping.

- 1918. Das nordische Kulturgebiet in Mitteleuropa während der jüngeren Steinzeit. I-II. Skrifter utgifna med understöd af Vilhelm Ekmans universitetsfond, Uppsala. 22:1-2. Uppsala/Leipzig. 
